\title{
Death Receptor Fas as Molecular Target of Soursop Leaves Novel Isolate in Liver Cancer Targeted Therapy
}

\author{
Maya Tejasari, ${ }^{1}$ Dwi Prasetyo, ${ }^{2}$ Siti Aminah Abdurachman, ${ }^{3}$ Herri S. Sastramihardja ${ }^{4}$ \\ ${ }^{1}$ Department of Histology, Faculty of Medicine, Universitas Islam Bandung, Bandung, Indonesia, \\ ${ }^{2}$ Department of Child Health, Faculty of Medicine, Universitas Padjadjaran/Dr. Hasan Sadikin General Hospital, \\ Bandung, Indonesia, ${ }^{3}$ Department of Internal Medicine, Faculty of Medicine, Universitas Padjadjaran/ \\ Dr. Hasan Sadikin General Hospital Bandung, ${ }^{4}$ Department of Farmacology, Faculty of Medicine, \\ Universitas Islam Bandung, Bandung, Indonesia
}

\begin{abstract}
In the past few decades, no effective systemic therapeutic modalities established in the unresectable liver cancer stage, so the prognosis remains poor. Apoptotic dysregulation of cancer cells through Fas gene expression linked to tumor development, progression, and resistance to treatment. Soursop plants believed to have potent anticancer activity. It hypothesized that active compounds in the soursop leaves would induce apoptosis by interfering with Fas gene expression in liver cancer cells. The study objective was to explore the role of an isolated from soursop leaves against Fas gene expression in liver cancer cells. This study used the HepG2 cell line culture, and treatment groups were given novel isolate ( $\mathrm{SF}-1603$ ) from soursop leaves with three different doses which conducted in Bandung in 2017. Observations assessed in hours $0,24,48$, and 72. Measurement of gene expression was done with real-time PCR and apoptosis detection by the TUNEL method. The results showed that the novel isolate (SF-1603) from soursop leaves stimulate Fas optimum expressions to initiate apoptosis with $0.5 \times$ inhibitory concentration $50\left(\mathrm{IC}_{50}\right)$ dosage at observation hour 48. There was a strong correlation between Fas gene expression with the apoptosis level. It concluded that the novel isolate (SF-1603) from soursop leaves is a potent anticancer that affects FAS gene expression in apoptosis induction on the liver cancer cell. It can be used as a candidate for a new therapeutic agent for liver cancer treatment.
\end{abstract}

Key words: Apoptosis, Fas gene expression, liver cancer, soursop, targeted therapy

\section{Reseptor Fas sebagai Sasaran Molekuler Novel Isolat Daun Sirsak pada Terapi Bertarget Kanker Hati}

\begin{abstract}
Abstrak
Dalam beberapa dekade terakhir, tidak ada modalitas terapi sistemik yang efektif untuk pengobatan kanker hati tahap lanjut sehingga prognosisnya buruk. Disregulasi apoptosis sel kanker melalui ekspresi gen Fas terkait dengan perkembangan, perkembangan tumor, dan resistensi terhadap pengobatan. Tanaman sirsak dipercaya memiliki aktivitas antikanker yang kuat. Senyawa aktif dalam daun sirsak secara hipotesis dapat menginduksi apoptosis dengan memengaruhi ekspresi gen Fas pada sel kanker hati. Tujuan penelitian adalah mengeksplorasi peran isolat daun sirsak terhadap ekspresi gen Fas pada sel kanker hati. Penelitian ini menggunakan kultur sel kanker HepG2 dan kelompok perlakuan diberi isolat baru (SF-1603) daun sirsak dengan 3 dosis berbeda yang dilakukan di Bandung pada tahun 2017. Pengamatan dinilai pada jam ke-o, 24, 48, dan 72. Pengukuran ekspresi gen dilakukan dengan PCR real-time dan deteksi apoptosis dengan metode TUNEL. Hasil penelitian menunjukkan bahwa novel isolat (SF-1603) daun sirsak menstimulasi ekspresi optimal Fas untuk inisiasi apoptosis dengan dosis $0,5 \times$ inhibitory concentration $50\left(\mathrm{IC}_{50}\right)$ pada pengamatan $48 \mathrm{jam}$. Terdapat korelasi yang kuat antara ekspresi gen Fas dan tingkat apoptosis. Disimpulkan bahwa isolat baru (SF-1603) daun sirsak adalah antikanker kuat yang memengaruhi ekspresi gen Fas dalam induksi apoptosis pada sel kanker hati sehingga dapat digunakan sebagai kandidat agen terapi baru untuk pengobatan kanker hati.
\end{abstract}

Kata kunci: Apoptosis, ekspresi gen Fas, kanker hati, sirsak, terapi bertarget 


\section{Introduction}

Cancer remains a global health problem that needs to encounter. Based on data from the World Health Organization (WHO) and the Global Burden of Cancer Study (GLOBOCAN), cancer is the most common cause of morbidity and mortality in the world..$^{1-3}$

Hepatocellular carcinoma (HCC), or often called hepatoma is a type of cancer most commonly found in the liver, ${ }^{4-10}$ reportedly caused half a million deaths each year. ${ }^{1,6}$ The American Cancer Society in 2010 estimated that the incidence and mortality of HCC would continue to rise until 2020.

The high mortality rate in HCC occurs because patients come to health facilities in an unresectable stage is challenging to handle. Recommended therapy based on the classification of the Barcelona Clinic Liver Cancer (BCLC) for HCC with an advanced stage is to approach the provision of palliative systemic chemotherapy. ${ }^{11-13}$ Another approach, such as curative resection and transplantation, can only be limited in patients with early-stage HCC. Chemotherapy is still the best option for patients with advanced HCC, the effectiveness of chemotherapy in patients with HCC remains in the debate instead of often considered to be relatively ineffective. The choice of therapy for patients with HCC who are still very limited is one of the causes of poor prognosis of liver cancer patient. ${ }^{6-9,14-16}$

Nowadays, many chemotherapeutic agents have been tested, but none that show a maximum response or provide a better life expectancy in patients with liver cancer. In addition to the relative effectiveness which is still lacking, chemotherapeutic agents that exist today can not separate from the high toxicity profile with severe side effects such as myelosuppression and neurotoxic effects and the emergence of resistance mechanisms. ${ }^{14-16}$ New therapeutic strategies needed to increase the effectiveness of therapy. ${ }^{14,15}$

Therapeutic strategies based on the target molecular pathways through signal transmission intervention and regulation of apoptosis, offering new hope for more effective therapy options. ${ }^{15,16}$

One potential target for liver cancer therapy that has not widely studied is the path through the mechanism of apoptosis. The carcinogenesis of HCC occurs during apoptosis dysregulation, so this pathway is the potential to be developed.
Apoptosis is a mechanism of programmed cell death induced by the intracellular controlled program. In the apoptosis process, cells that should die activates proteolytic enzymes. ${ }^{11-13}$ Apoptosis plays in suppressing liver disease, either through the intrinsic and extrinsic pathway, as well as disorders of the mitochondria. ${ }^{21,22}$

Initiation extrinsic pathway involves the role of one of the death receptor Fas. The intrinsic pathway involving the antiapoptosis molecule, Bcl2, and IAP. ${ }^{2}$ High Bcl-2 gene expression is known to be protective mechanisms to deal with various stimuli that cause cell death. ${ }^{19,20}$ Apoptosis plays a role in suppressing liver disease progression through both intrinsic and extrinsic pathways. ${ }^{21,22}$ Dysregulation of apoptotic cells influence the process of carcinogenesis, tumor progression, and the tumor radio-resistance to chemotherapy, therefore the development of anticancer agents by inducing apoptosis is a potential therapeutic target of HCC treatment. ${ }^{23}$

Dysregulation of apoptosis occurs in carcinogenesis of HCC; it causes inhibition of apoptosis in the initiation phase, both extrinsic and intrinsic pathways, that the cells do not die. ${ }^{21,22}$ The incidence of HCC is associated with low expression of Fas, a cell death surface receptor that can inhibit the initiation of the extrinsic apoptosis pathway.,4,18,24 In the pathogenesis of HCC, there was also found increasing of the inhibitor of apoptosis protein (IAP) and high expression of Bcl-2, which is antiapoptosis proteins that inhibit apoptosis initiation through the intrinsic pathway..$^{17,25}$

Receptor Fas, also known as apoptosis antigen 1 (APO1), cluster of differentiation 95 (CD95) or tumor necrosis factor receptor superfamily member 6 (TNFRSF6), is a protein that in humans is encoded by the gene TNFRSF6 or officially based on the HUGO Gene Nomenclature Committee (HGNC) known as Fas gene. Fas gene in humans is located at the locus in the long arm of chromosome 10 (10q24.1), with a length of 25,255 DNA base and has nine types of proteincoding exons. ${ }^{24,26,27}$

Fas receptor is a transmembrane surface protein that plays a role in the initiation of apoptosis. This protein consists of 319 amino acids with a molecular weight of 49 kiloDalton and consists of three domains: the extracellular domain, a transmembrane domain, and a cytoplasmic domain. The extracellular domain consists of 157 amino acids and rich in cysteine 
residues, whereas the transmembrane domain consists of seven amino acids, and the cytoplasmic domain consists of 145 amino acids. ${ }^{26,27}$

Fas receptor formed death-inducing signaling complex (DISC) with its ligands, namely FasL resulting Fas receptor trimerization. This receptor complex is internalized and binds to adapter molecules with FADD death effector domain (DED) and facilitates bonding with FADD-like IL-1 $\beta$-converting enzyme (FLICE) or better known as caspase-8. Caspase-8 is activated and then released into the cytoplasm, which then triggers the caspase cascade and ends with the degradation of DNA and other signs that are the hallmark of apoptosis. ${ }^{24,26,27}$

Natural materials are a source of potential therapeutic agents with many advantages; they are readily available, inexpensive, and have minimal side effects. ${ }^{19}$ Many compounds derived from natural materials have anti-tumor properties. Indonesia is rich in natural content that the community trusted to prevent and even treat cancer, one of which is Annona muricata Linn generally known as soursop or guava. ${ }^{16-19}$

Almost all parts of the soursop plant reported to use in traditional medicine but have not done much scientific research to examine in detail what kind of substances exist in each part of the soursop plant that has an active property. ${ }^{20-23}$ This study aims to explore the capabilities of the novel pure compound (SF-1603) isolated from the soursop leaves in apoptosis induction of HCC cell culture, so it is used as a candidate for new agent discovery to treat liver cancer patients.

\section{Methods}

This study was conducted in Bandung in 2017. Materials used in this study was the pure compound isolated from the soursop leaves code $\mathrm{SF}-1603$ as a result from our previous study, ${ }^{28}$ HepG2 cell line (HB-8065TM) from the American Type Culture Collection (ATCC), Dulbecco's Modified Eagle Medium (DMEM ) containing $10 \%$ fetal bovine serum (FBS), penicillin, streptomycin and trypsin for cell culture, as well as in situ TUNEL Cell Death Detection Kit from Roche.

HepG2 cell line cultured in medium (DMEM/ F12) containing $10 \%$ fetal bovine serum, previously release cells using trypsin $0.05 \%$ EDTA $0.53 \mathrm{~mm}$, then added to the growth medium into a cell suspension. The cells were counted using a hemocytometer and planted with a cell density of 25,000 cells $/ \mathrm{mL}$. The cells incubated, and the growth medium was changed every two days.

The method for detecting cells undergoing apoptosis based on apoptosis's characteristics that one of them is going on DNA fragmentation. A standard method used to detect DNA fragmentation enzymatically sings the TUNEL method. TUNEL reagent consisting of terminal transferase enzyme served to identify the ends $3{ }^{\prime} \mathrm{OH}$ (nick-end) generated by DNA fragmentation and fluorescein-dUTP to visualize the end $3^{\prime} \mathrm{OH}$ observed using an inverted microscope.

This study using real-time PCR for quantitative analysis. The work of real-time PCR is similar to conventional RT-PCR. The fundamental difference of (1) analysis of amplicons using fluorescent reporters and not using conventional gel electrophoresis, (2) amplicon analyzed from each cycle, and not only when the endpoint. This study uses SsoFastTMEvaGreen SUPERMIX containing a mixture of ready-made for the qPCR reaction except for the primer and template, i.e., $2 \times$ reaction buffer with dNTPs, sso7d-fusion polymerase, $\mathrm{MgCl}$ 2, EvaGreen dye, and stabilizers.

Fas gene primer used:

Forward 5'-TCC TCC AGG TGA AAG GAA AGC TAG G-3'

Reverse 5 -AGA TTG TGT GAT GAA GGA CAT GGC-3'

This study has obtained ethical approval from the Health Research Ethics Committee Faculty of Medicine Universitas Padjadjaran Bandung No. 988/UN6.C2.1.2/KEPK/PN/2O17.

\section{Results}

The ability of the pure compound $\mathrm{SF} 1603$ in stimulating the expression of FAS can see from the Fas mRNA expression profile. It indicates the level of Fas expression over the control group in the group treated with doses $0.5 \times \mathrm{IC}_{50}$ and observed on $48^{\text {th }}$ hour (Figure), reinforced with statistical calculations with a mean comparison test which indicates the optimum level expression of Fas by taking into account dose and time, showed similar results. The ANOVA statistical tests prove to strengthen significantly different Fas mRNA expression between each group at all doses and time of observation. The ANOVA test shows that the value of $F_{\text {count }}>F_{\text {table }}$ (0.05), it can conclude there was a significant difference in 


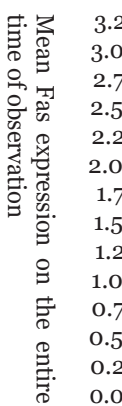

Figure Influence of Dose and Time of Observation against Fas Gene Expression after Administration of Soursop Leaves Pure Compounds SF-1603 in HepG2 Cell Line Culture Showed Fas Optimum Expressions to Initiate Apoptosis with $0.5 \times \mathrm{IC}_{50}$ Dosage at Observation Hour 48

mRNA Fas expression between groups at all doses and observation times, in the HepG2 cell line cultured after administration of the compound SF-1603.

To measure the strength of the correlation between Fas mRNA expression and apoptosis level, then performed a simple correlation coefficient calculation using the Pearson formula. The calculation results conclude the presence correlation between Fas mRNA expression and the level of apoptosis with $\mathrm{r}=0.587$, which means the strength of the correlation is strong enough. Level of apoptosis and inhibitory concentration $\left(\mathrm{IC}_{50}\right)$ of $\mathrm{SF}-1603$ was a result of our previous study. ${ }^{28}$

\section{Discussion}

Apoptosis is a mechanism of programmed cell death induced by the intracellular controlled program. In the apoptosis process, cells that should die activates proteolytic enzymes. ${ }^{11-13}$ Apoptosis plays in suppressing liver disease, either through the intrinsic and extrinsic pathway, as well as disorders of the mitochondria. ${ }^{21-22}$

In the pathogenesis of hepatocellular carcinoma, dysregulation of apoptosis occurs in low expression of the Fas receptor. It inhibits the activation of caspase- 8 and caspase- 3 . Thus, it inhibits apoptosis.

Based on the soursop leaves pure compound SF-1603 ability to stimulate Fas gene expression, thereby increasing the expression of the death receptor Fas. The compound can be used as a candidate therapeutic agent of HCC. As the

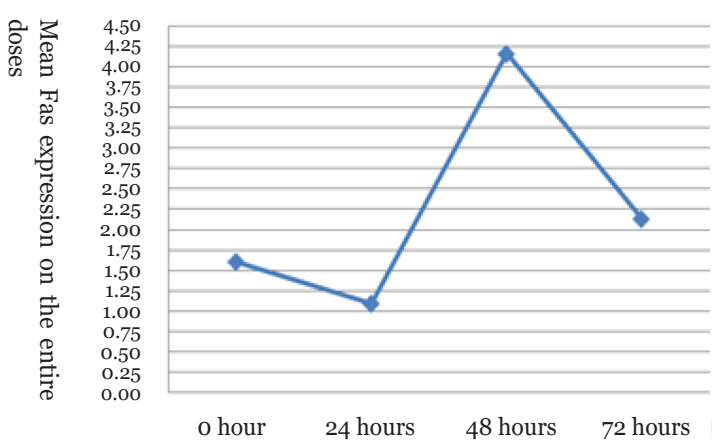

molecular target therapy, the Fas gene initiates the induction of apoptosis in liver cancer cells.

Fas receptor formed death-inducing signaling complex (DISC) with its ligands, namely FasL resulting Fas receptor trimerization. This receptor complex is internalized and binds to adapter molecules with the FADD death effector domain (DED) and facilitates bonding with FADD-like IL-1 $\beta$-converting enzyme (FLICE) or better known as caspase-8. Caspase-8 is activated and then released into the cytoplasm, which then triggers the caspase cascade and ends with the degradation of DNA and other signs that are the hallmark of apoptosis. ${ }^{24,26,27}$

Based on the analysis of gene expression, it means that the study proves the ability of the soursop leaves pure compound SF-1603 to induce the expression of Fas through the mechanism of stimulation of Fas gene expression in HCC cancer cells so that it can initiate the process of apoptosis. Proof of this is very supportive of making the soursop leaves pure compound SF1603 as a candidate for liver cancer therapeutic agent with the Fas gene as a molecular target therapy through the mechanism of apoptosis induction.

The pathway involving Fas is selective; it does not cause normal cell death, so that it is very good to be the target of therapy for cancer.

\section{Conclusion}

It concluded that the soursop leaves pure compound SF-1603 have a potent anticancer activity that affects Fas gene expression as a 
molecular target. It can use as a candidate for a new therapeutic agent for liver cancer treatment.

\section{Conflict of Interest}

On behalf of all authors, the corresponding author states that there is no conflict of interest.

\section{References}

1. Bray F, Ferlay J, Soerjomataram I, Siegel RL, Torre LA, Jemal A. Global cancer statistics 2018: GLOBOCAN estimates of incidence and mortality worldwide for 36 cancers in 185 countries. CA Cancer J Clin. 2018;68(6):394-424.

2. Forner A, Llovet JM, Bruix J. Hepatocellular carcinoma.Lancet.2018;391(10127):1301-14.

3. Schwartz JM, Carithers RL. Epidemiology and etiologic associations of hepatocellular carcinoma [Internet]. Guadalajara, Mexico: Sociedad Mexicana de Podología Médica AC (Somepomed); 2011 [cited 2019 November 18]. Available from: http://somepomed. org/articulos/contents/mobipreview. htm?8/29/8657.

4. Theise ND. Liver and gallbladder. In: Kumar V, Abbas AK, Aster JC, editors. Robbins and Cotran pathologic basis of disease. $9^{\text {th }}$ Edition. Philadelphia, USA: Elsevier Saunders; 2015. p. 821-82.

5. Alqahtani A, Khan Z, Alloghbi A, Said Ahmed TS, Ashraf M, Hammouda DM. Hepatocellular carcinoma: molecular mechanisms and targeted therapies. Medicina (Kaunas). 2019;55(9):526.

6. Ho HK, Pok S, Streit S, Ruhe JE, Hart S, Lim KS, et al. Fibroblast growth factor receptor 4 regulates proliferation, anti-apoptosis and alpha-fetoprotein secretion during hepatocellular carcinoma progression and represents a potential target for therapeutic intervention. J Hepatol. 2009;50(1):118-27.

7. Huynh H, Ngo VC, Koong HN, Poon D, Choo SP, Toh HC, et al. AZD6244 enhances the anti-tumor activity of sorafenib in ectopic and orthotopic models of human hepatocellular carcinoma (HCC). J Hepatol. 2010;52(1):7987.

8. Robotin MC, Kansil M, Howard K, George J, Tipper S, Dore GJ, et al. Antiviral therapy for hepatitis B-related liver cancer prevention is more cost-effective than cancer screening. J
Hepatol. 2009;50(5):990-8.

9. Lencioni R, Crocetti L, Petruzzi P, Vignali C, Bozzi W, Pina CD, et al. Doxorubicin-eluting bead-enhanced radiofrequency ablation of hepatocellular carcinoma: a pilot clinical study. J Hepatol. 2008;49(2):217-22.

10. Cardoso AC, Moucari R, Figueiredo-Mendes C, Ripault MP, Giully N, Castelnau C, et al. Impact of peginterferon and ribavirin therapy on hepatocellular carcinoma: incidence and survival in hepatitis $\mathrm{C}$ patients with advanced fibrosis. J Hepatol. 2010;52(5):652-7.

11. Vogell A, Cervantes A, Chau I, Daniele B, Llovet JM, Meyer T, et al.; ESMO Guidelines Committee. Hepatocellular carcinoma: ESMO Clinical Practice Guidelines for diagnosis, treatment and follow-up. Ann Oncol. 2018;29(Suppl 4):iv238-55.

12. Bruix J, Sherman M; American Association for the Study of Liver Diseases. Management of hepatocellular carcinoma: an update. Hepatology. 2011;53(3):1020-2.

13. Sherman M, Burak K, Maroun J, Metrakos P, Knox JJ, Myers RP, et al. Multidisciplinary Canadian consensus recommendations for the management and treatment of hepatocellular carcinoma. Curr Oncol. 2011;18(5):228-40.

14. Park SH, Lee Y, Han SH, Kwon SY, Kwon OS, Kim SS, et al. Systemic chemotherapy with doxorubicin, cisplatin and capecitabine for metastatic hepatocellular carcinoma. BMC Cancer. 2006;6:3.

15. Abou-Alfa GK. Current and novel therapeutics for hepatocellular carcinoma. In: American Society of Clinical Oncology 2004 educational book ( $4 \mathrm{O}^{\text {th }}$ Annual Meeting June 5-8, 2004 New Orleans, LA). Alexandria, USA: American Society of Clinical Oncology; 2004. p. 192-7.

16. Wirth T, Kühnel F, Fleischmann-Mundt B, Woller N, Djojosubroto M, Rudolph KL, et al. Telomerase-dependent virotherapy overcomes resistance of hepatocellular carcinomas against chemotherapy and tumor necrosis factor-related apoptosis-inducing ligand by the elimination of Mcl-1. Cancer Res. 2005;65(16):7393-402.

17. Chang YC, Xu YH. Expression of Bcl-2 inhibited Fas-mediated apoptosis in human hepatocellular carcinoma BEL-7404 cells. Cell Res. 2000;10(3):233-42.

18. El Bassiouny AEI, Nora E I El-Bassiouni NEI, 
Nosseir MMF, Zoheiry MMK, El-Ahwany EG, Salah F, et al. Circulating and hepatic Fas expression in HCV-induced chronic liver disease and hepatocellular carcinoma. Medscape J Med. 2008;10(6):130.

19. Saikumar P. Apoptosis and cell death. In: Cagle PT, Allen TC, editors. Basic concept of molecular pathology. New York: Springer Science+Bussines Media; 2009. p. 29-40.

20. Marschitz I, Tinhofer I, Hittmair A, Egle A, Kos M, Greil R. Analysis of Bcl-2 protein expression in chronic lymphocytic leukemia. A comparison of three semiquantitation techniques. Am J Clin Pathol. 2000;113(2): 219-29.

21. Liu Q, Chen J, Liu L, Zhang J, Wang D, $\mathrm{Ma} \mathrm{L}$, et al. The X protein of hepatitis $B$ virus inhibits apoptosis in hepatoma cells through enhancing the methionine adenosyltransferase $2 \mathrm{~A}$ gene expression and reducing S-adenosylmethionine production. J Biol Chem. 2011;286(19):17168-80.

22. He H, Wu X, Yu B, Liu K, Zhou G, Qian G, et al. The effect of desacetyluvaricin on the expression of TLR4 and $\mathrm{P}_{53}$ protein in Hepg 2.2.15. Hepat Mon. 2011;11(5):364-7.

23. Hsieh SY, Hsu CY, He JR, Liu CL, Lo SJ, Chen YC, et al. Identifying apoptosis-evasion proteins/pathways in human hepatoma cells via induction of cellular hormesis by UV ifradiation. J Proteome Res. 2009;8(8):3977-
86.

24. Lee SH, Shin MS, Lee HS, Bae JH, Lee HK, Kim HS, et al. Expression of Fas and Fasrelated molecules in human hepatocellular carcinoma. Hum Pathol. 2001;32(3):250-6.

25. Yildiz L, Baris S, Aydin O, Kefeli M, Kandemir B. Bcl-2 positivity in $\mathrm{B}$ and $\mathrm{C}$ hepatitis and hepatocellular carcinomas. Hepatogastroeneterology. 2008;55(88): 2207-10.

26. Rodriguez ML, Estrela JM, Ortega AL. Natural polyphenols and apoptosis induction in cancer therapy. J Carcinogene Mutagene. 2013;S6:004.

27. Crown Human Genome Center, Department of Molecular Genetics, Weizmann Institute of Science. Fas cell surface death receptor (previous names: tumor necrosis factor receptor superfamily, member 6, Fas) [Internet]. Rehovot, Israel: Weizmann Institute of Science; 2019 [cited 2019 November 20]. Available from: https:// genecards.weizmann.ac.il/v3/cgi-bin/ carddisp.pl?gene $=$ FAS.

28. Tejasari M, Sastramihardja HS, Abdurrachman SA, Prasetyo D. Anticancer activity of novel soursop leaves active compound (SF-1603) through apoptotic induction in liver cancer. MJFAS. 2018;14(2): 226-34. 